\title{
Transatlantica
}

Revue d'études américaines. American Studies Journal

\section{Reminiscing Eudora Welty}

Pearl Amelia McHaney

\section{(2) OpenEdition}

\section{Journals}

Édition électronique

URL : http://journals.openedition.org/transatlantica/339

DOI : 10.4000/transatlantica.339

ISSN : 1765-2766

Éditeur

AFEA

\section{Référence électronique}

Pearl Amelia McHaney, «Reminiscing Eudora Welty », Transatlantica [En ligne], 1 | 2001, mis en ligne le 11 avril 2006, consulté le 29 avril 2021. URL : http://journals.openedition.org/transatlantica/339 ; DOI : https://doi.org/10.4000/transatlantica.339

Ce document a été généré automatiquement le 29 avril 2021.

\section{(c) (i) (9)}

Transatlantica - Revue d'études américaines est mis à disposition selon les termes de la licence Creative Commons Attribution - Pas d'Utilisation Commerciale - Pas de Modification 4.0 International. 


\title{
Reminiscing Eudora Welty
}

\author{
Pearl Amelia McHaney
}

1 After several years of reading Welty and after the thrill of meeting her in the old Capitol in Jackson upon the occasion of her 75th birthday, I chatted with her as with an old friend in my dreams one night. The setting seemed at first fantastical, fairylike. She came out of a rustic cabin and joined my mother, sister, and me at a picnic table under the tall pines and maples of the Catskill Mountains. It was after this dream that I had the courage to write to Welty to ask her the questions I could not answer. Several times I had been deterred for fear of bothering the author. But, at last, I felt I had questions that only Eudora Welty could answer, and the dream conversation gave me courage, or maybe license, to send my queries to her address.

One day, standing on my porch, shuffling through the mail, I froze to see Welty's return address on an envelope. I was shocked to find my own letter inside. Had she rejected me outright? No. She had annotated my letter :

Dear Ms. McHaney,

Please excuse the looks of this-I started out jotting down a few replies and over-ran my space. I'm sending it on in case any of it is useful to you.

Sincerely, Eudora Welty

3 Most of my questions were about Welty's reviews for the New York Times Book Review where four reviews by Michael Ravenna had been published. It was known that Welty had written three of them. But rumors about the choice of pseudonym were many. Was it because she was a woman reviewing two war novels and George Biddle's Artist at War (1944)? "None of this is correct," she wrote. "[B]eing a woman had nothing to do with it." Why had she chosen Michael Ravenna? For Ravenna, Italy? No. "Just a name that occurred to me, of no import. Why not Michael Ravenna?"

4 In the ensuing conversations, for I was among the luckiest of scholars to be welcomed into her living room crowded with stacks of books and papers and awards, we chatted further about book reviews and her Jackson friends who had left long ago for New York. Although I stubbornly refused the news at first, I finally accepted that Nash K. Burger, the friend she had suggested for fulltime work at the Book Review, had 
borrowed and perpetuated the pseudonym himself. The only Ravenna review inked by Welty was Artist at War. "Why not?" said both Welty and Burger.

The annotated letter came ten years ago. Since then, my greatest joy and my continuing pleasure has been to read Welty's writing, to excite others about it, to show readers where they are in her world of fiction, to brag that I knew more about Welty than I did about myself. The first story by her that I read (meeting her in another unlikely place-on the eastern beaches of Lake Michigan) was "Clytie," but knowing Welty and reading her work are the antithesis of the experience of Clytie's trapped, anxious, desperate life. Now, I fill my head and heart with other wondrous moments from Welty's fiction: Jenny's "shock of love" in "At the Landing," Dr. Strickland's "assault of hope" in "The Demonstrators," Nina Carmichael's whispered dream, "To have been an orphan" in that glorious story "Moon Lake," and the imagined sound of Bonnie Dee Peacock's "mosquitoey voice."

One of my favorite gifts from Welty's genius is another of Nina's musings, as she floats out onto Moon Lake in the tethered rowboat:

Again she thought of a pear-not the every day gritty kind that hung on the tree in the backyard, but the fine kind sold on trains and at high prices, each pear with a paper cone wrapping it alone-beautiful, symmetrical, clean pears with thin skins, with snow-white flesh so juicy and tender that to eat one baptized the whole face, and so delicate that while you urgently ate the first half, the second half was already beginning to turn brown. ("Moon Lake")

7 Although Eudora Welty lived a glorious 92 years, it seems too brief a life, until I recall that she always urged the readers of her book reviews to read the fiction, look for the authors there, watching their characters live lives to behold. My heart is full, my mind is soaring, and my eyes see wonders when I look at the pages Eudora Welty filled for me, for all of us.

\section{INDEX}

Thèmes : Trans'Arts

\section{AUTEUR}

\section{PEARL AMELIA MCHANEY}

Ms McHaney is the editor of the Eudora Welty Newsletter. She also edited Eudora Welty: Collected Book Reviews (U P Mississippi, 1995) and Eudora Welty: Writers' Reflections upon First Reading Her Work (Hill Street Press, 1999), a tribute to Welty for her 90th birthday. She teaches American literature at Georgia State University in Atlanta, Georgia. 